\title{
MAINTENANCE OF THE MOTILITY OF RAT EPIDIDYMAL SPERMATOZOA IN THE PRESENCE OF MALE ACCESSORY SECRETIONS
}

\author{
Z. MORITA* AND M. C. GHANG \\ Worcester Foundation for Experimental Biology, \\ Shrewsbury, Massachusetts 01545, U.S.A.
}

(Received 20th April 1970)

\begin{abstract}
Summary. The maintenance of motility and the survival of rat epididymal spermatozoa kept at $37^{\circ} \mathrm{C}$ have been investigated. While progressive motility of long duration was observed when the epididymal spermatozoa of the hamster, guinea-pig and rabbit were suspended in balanced salt solutions, rat epididymal spermatozoa became immotile within 1 to $2 \mathrm{hr}$. The factor missing from the salt solutions which can maintain the motility of rat spermatozoa was shown to be present in the secretion from the seminal vesicles, epididymis and coagulating gland of the rat. The most effective factor occurred in the secretion of the seminal vesicles of the hamster, and was found to be unstable, thermolabile and undialysable through the collodion bag filter which retains proteins of a molecular weight of approximately 70,000 to 100,000 . By means of electrophoretic separation, three fractions with the low mobility of serum $\gamma$-and $\beta$-globulins were detected in the fresh secretion of the seminal vesicles of the hamster. The motility of rat epididymal spermatozoa was better maintained in solutions containing protein, such as albumin, $\alpha$-globulin, or peptides like glutathione or cysteine. It appears that a non-specific protein which is supplied by the seminal vesicles is necessary to maintain the motility of rat spermatozoa.
\end{abstract}

\section{INTRODUCTION}

A considerable literature has recently accumulated on electro-ejaculation in rats for the collection of spermatozoa for artificial insemination (Ogawa \& Suzuki, 1955, 1956; Scott \& Dziuk, 1959; Lawson, Krise \& Sorensen, 1967) and for biological research (Blandau \& Money, 1944; Slater, 1956; Okigaki, 1958; Blandau \& Rumery, 1961, 1964; Toyoda \& Chang, 1968). There is as yet no information on reliable methods for maintaining the motility of rat spermatozoa in vitro over a long period.

In an attempt to store rat spermatozoa, Ogawa \& Suzuki (1956) found that motility was better maintained in the supernatant fluids of the liver and brain tissues, homogenized either in a $0.9 \% \mathrm{NaCl}$ solution or in a $5 \%$ glucose solution,

\footnotetext{
* Present address: Faculty of Agriculture, Tottori University, Tottori, Japan.
} 
than in diluents generally used for the artificial insemination of domestic animals.

In view of the natural sequence of fertilization, it is reasonable to expect that some substances in the accessory glands may be essential for the physiological activity of rat spermatozoa. The present paper reports the results of investigations into the requirements for the maintenance of motility and survival of rat spermatozoa kept at $37^{\circ} \mathrm{C}$.

\section{MATERIALS AND METHODS}

\section{Sperm suspension and male accessory secretions}

A few drops of spermatozoa (about $0.1 \mathrm{ml}$ ) were pressed out from the cauda epididymidis of the rat, hamster, guinea-pig and rabbit and then mixed with 2 $\mathrm{ml}$ of Hanks' solution containing penicillin $(50 \mu \mathrm{g} / \mathrm{ml})$ and glucose $(1 \mathrm{mg} / \mathrm{ml})$.

Male accessory glands were dissected out and placed on watch glasses. A few drops of secretion $(0.1$ to $0.2 \mathrm{ml})$ from the seminal vesicles, coagulating gland and ventral or dorsal prostate were mixed with $0.5 \mathrm{ml}$ of Hanks' solution.

\section{Motility}

For the observation of sperm motility, one drop of sperm suspension (about $0.04 \mathrm{ml}$ ) in a watch glass was mixed with five drops (about $0.2 \mathrm{ml}$ ) of each diluted accessory secretion, covered with mineral oil and incubated at $37^{\circ} \mathrm{C}$. The final concentration of spermatozoa in the mixture was about 0.2 to $0.4 \times$ $10^{8} / \mathrm{ml}$. The motility of spermatozoa in the watch glass was observed $1 \mathrm{hr}$ after preparation and then every $2 \mathrm{hr}$ for $24 \mathrm{hr}$ under a compound microscope $(10 \times 20)$ placed in a warm chamber (at about $33^{\circ} \mathrm{C}$ ). The grade of motility was recorded according to the system of Emmens (1947). Recordings were made of the duration in hours that the initial progressive motility was maintained and the length of time to the complete cessation of motility. The range of at least three replications in terms of the duration of motility was presented.

\section{Electrophoresis}

Some experiments were made to determine the nature of various proteins in the secretions, using disc electrophoresis in polyacrylamide gel under the condition of $3 \mathrm{~mA}$ of constant current per column for $60 \mathrm{~min}$ in tris-glycine buffer at $\mathrm{pH} 8 \cdot 6$.

\section{RESULTS}

Short survival of rat spermatozoa in balanced salt solutions

The duration of maintenance of the initial progressive motility of the rat spermatozoa was found to be extremely short ( 1 or $2 \mathrm{hr}$, Table 1 ) even in Tyrode or Hanks' solution which contained glucose and $\mathrm{NaHCO}_{3}$, although a small number of spermatozoa showing a sluggish motion, survived for a longer time (10 to $24 \mathrm{hr}$ ). The epididymal spermatozoa of hamster, guinea-pig and rabbit, however, showed good initial motility and their motility was maintained in a balanced salt solution for 6 to $12 \mathrm{hr}$. 
Several trials involving slight variations in the balance of inorganic components, ionic strength, tonicity, $\mathrm{pH}$ value, substrates, or gases in the media, showed that these were not the major factors responsible for the poor motility of rat spermatozoa.

Motility in the presence of accessory secretions

Table 2 presents the results concerning the effect of various secretions from the male accessory glands on the motility of rat and hamster spermatozoa. It was found that the motility of rat spermatozoa was better maintained when a few drops $(0.1$ to $0.2 \mathrm{ml})$ of the secretion from the rat coagulating gland were added to the supernatant from the secretions of the rat seminal vesicles. Moreover, fresh secretions from the hamster seminal vesicle greatly prolonged the

TABLE 1

DURATION OF MOTILITY OF EPIDIDYMAL SPERMATOZOA OF HAMSTER, RAT, GUINEA-PIG AND RABBIT IN VARIOUS BALANCED SALT SOLUTIONS

\begin{tabular}{|c|c|c|c|c|c|c|c|c|c|}
\hline \multirow{3}{*}{\multicolumn{2}{|c|}{$\begin{array}{l}\text { Solutions } \\
\text { used } \\
\left.\quad \begin{array}{l}\text { Glucose } \\
(1 \mathrm{mg} / \mathrm{ml})\end{array}\right)\end{array}$}} & \multicolumn{8}{|c|}{ Duration of motility of epididymal spermatozoa $(h r)$} \\
\hline & & \multicolumn{2}{|c|}{ Hamster } & \multicolumn{2}{|c|}{ Rat } & \multicolumn{2}{|c|}{ Guinea-pig } & \multicolumn{2}{|c|}{ Rabbit } \\
\hline & & $A$ & B & $A$ & B & $A$ & $B$ & $A$ & B \\
\hline Ringer & $\bar{t}$ & $\begin{array}{r}8 \text { to } 10 \\
10 \text { to } 12\end{array}$ & $\begin{array}{l}12 \text { to } 24 \\
12 \text { to } 24\end{array}$ & $\begin{array}{l}0 \text { to } 2 \\
0 \text { to } 2\end{array}$ & $\begin{array}{l}12 \text { to } 24 \\
6 \text { to } 8\end{array}$ & $\begin{array}{l}6 \text { to } 8 \\
0 \text { to } 2\end{array}$ & $\begin{array}{l}8 \text { to } 10 \\
6 \text { to } 8\end{array}$ & $\begin{array}{l}6 \text { to } 8 \\
0 \text { to } 2\end{array}$ & $\begin{array}{l}8 \text { to } 12 \\
6 \text { to } 8\end{array}$ \\
\hline Locke & $\overline{+}$ & $\begin{array}{c}0 \text { to } 2 \\
10 \text { to } 12\end{array}$ & $\begin{array}{l}12 \text { to } 24 \\
12 \text { to } 24\end{array}$ & $\begin{array}{l}0 \text { to } 2 \\
0 \text { to } 2\end{array}$ & $\begin{array}{l}12 \text { to } 24 \\
10 \text { to } 12\end{array}$ & $\begin{array}{l}6 \text { to } 8 \\
2 \text { to } 4\end{array}$ & $\begin{array}{l}8 \text { to } 10 \\
8 \text { to } 10\end{array}$ & $\begin{array}{l}6 \text { to } 8 \\
2 \text { to } 4\end{array}$ & $\begin{array}{l}8 \text { to } 10 \\
6 \text { to } 8\end{array}$ \\
\hline Tyrode & $\bar{t}$ & $\begin{array}{c}0 \text { to } 2 \\
10 \text { to } 12\end{array}$ & $\begin{array}{l}12 \text { to } 24 \\
12 \text { to } 24\end{array}$ & $\begin{array}{l}0 \text { to } 2 \\
0 \text { to } 2\end{array}$ & $\begin{array}{l}12 \text { to } 24 \\
12 \text { to } 24\end{array}$ & $\begin{array}{c}0 \text { to } 2 \\
10 \text { to } 12\end{array}$ & $\begin{array}{r}8 \text { to } 10 \\
12 \text { to } 24\end{array}$ & $\begin{array}{c}2 \text { to } 4 \\
10 \text { to } 12\end{array}$ & $\begin{array}{r}8 \text { to } 10 \\
12 \text { to } 24\end{array}$ \\
\hline Hanks & - & $\begin{array}{c}0 \text { to } 2 \\
10 \text { to } 12\end{array}$ & $\begin{array}{l}12 \text { to } 24 \\
12 \text { to } 24\end{array}$ & $\begin{array}{l}0 \text { to } 2 \\
0 \text { to } 2\end{array}$ & $\begin{array}{l}12 \text { to } 24 \\
10 \text { to } 12\end{array}$ & $\begin{array}{l}1 \text { to } 2 \\
6 \text { to } 8\end{array}$ & $\begin{array}{r}8 \text { to } 10 \\
10 \text { to } 12\end{array}$ & $\begin{array}{l}4 \text { to } 6 \\
6 \text { to } 8\end{array}$ & $\begin{array}{r}8 \text { to } 10 \\
10 \text { to } 12\end{array}$ \\
\hline
\end{tabular}

A: Incubation period for the maintenance of the initial progressive motility. B: Incubation period when no motility was observed.

motility of rat spermatozoa. This beneficial factor was also present in the secretions of the epididymis of the rat and hamster and in the coagulating gland of the hamster (Table 2).

\section{Effect of dilution on the motility}

In order to test the effect of dilution, one drop (about $0.02 \mathrm{ml}$ ) of rat epididymal sperm suspension was mixed with one, three, five, eight or ten drops of Hanks' solution or with fresh secretions from the hamster seminal vesicles (Table 3). In the seminal vesicle secretion, progressive motility was maintained for 8 to $12 \mathrm{hr}$. A dilution of $1: 5$ or 1:8 was better for the maintenance of motility ( 8 to $12 \mathrm{hr}$ ) than a dilution of $1: 1$ or $1: 3$ (4 to $8 \mathrm{hr}$ ).

When mixed with Hanks' solution alone, progressive motility was preserved for a longer period ( 2 to $4 \mathrm{hr}$ ) at the dilution rate of $1: 1$ or $1: 3$, than at the dilution rate of $1: 5$ or $1: 8$ ( 1 to $2 \mathrm{hr}$ ). 
Some physico-chemical properties of the beneficial factor

Some experiments were undertaken to investigate the properties of this factor in the fresh secretion of the hamster seminal vesicle (Table 4). The ability of the secretions to maintain motility was partially lost during storage

TABLE 2

DURATION OF MOTILITY OF EPIDIDYMAL SPERMATOZOA OF RAT AND HAMSTER IN THE PRESENCE OF ACGESSORY GLAND SEGRETIONS

\begin{tabular}{|c|c|c|c|c|c|}
\hline & \multirow{3}{*}{$\begin{array}{l}\text { Source of } \\
\text { secretions }\end{array}$} & \multicolumn{4}{|c|}{ Duration of motility of epididymal spermatozoa $(h r)$} \\
\hline & & \multicolumn{2}{|c|}{ Rat } & \multicolumn{2}{|c|}{ Hamster } \\
\hline & & $A$ & $\boldsymbol{B}$ & $A$ & $B$ \\
\hline Rat & $\begin{array}{l}\text { Epididymis } \\
\text { Seminal vesicle* } \\
\text { Seminal vesicle } \dagger \\
\text { Coagulating gland } \\
\text { Ventral prostate } \\
\text { Dorsal prostate }\end{array}$ & $\begin{array}{l}8 \text { to } 10 \\
0 \text { to } 1 \\
6 \text { to } 8 \\
2 \text { to } 4 \\
0 \text { to } 1 \\
2 \text { to } 4\end{array}$ & $\begin{array}{l}12 \text { to } 24 \\
1 \text { to } 2 \\
8 \text { to } 10 \\
6 \text { to } 8 \\
0 \text { to } 1 \\
6 \text { to } 8\end{array}$ & $\begin{array}{l}10 \text { to } 12 \\
0 \text { to } 1 \\
10 \text { to } 12 \\
2 \text { to } 4 \\
1 \text { to } 2 \\
1 \text { to } 2\end{array}$ & $\begin{array}{r}12 \text { to } 24 \\
2 \text { to } 4 \\
12 \text { to } 24 \\
4 \text { to } 6 \\
4 \text { to } 6 \\
4 \text { to } 6\end{array}$ \\
\hline Hamster & $\begin{array}{l}\text { Epididymis } \\
\text { Seminal vesicle* } \\
\text { Seminal vesicle } \dagger \\
\text { Coagulating gland } \\
\text { Ventral prostate } \\
\text { Dorsal prostate }\end{array}$ & $\begin{array}{l}8 \text { to } 10 \\
8 \text { to } 10 \\
8 \text { to } 10 \\
8 \text { to } 10 \\
4 \text { to } 6 \\
4 \text { to } 6\end{array}$ & $\begin{array}{l}12 \text { to } 24 \\
12 \text { to } 24 \\
12 \text { to } 24 \\
8 \text { to } 10 \\
4 \text { to } 6 \\
8 \text { to } 10\end{array}$ & $\begin{array}{l}10 \text { to } 12 \\
10 \text { to } 12 \\
10 \text { to } 12 \\
8 \text { to } 10 \\
0 \text { to } 1 \\
8 \text { to } 10\end{array}$ & $\begin{array}{l}12 \text { to } 14 \\
12 \text { to } 24 \\
12 \text { to } 24 \\
12 \text { to } 24 \\
0 \text { to } 1 \\
12 \text { to } 24\end{array}$ \\
\hline \multicolumn{2}{|c|}{ Saline diluent (control) } & 0 to 2 & 10 to 12 & 10 to 12 & 12 to 24 \\
\hline
\end{tabular}

A: Incubation period for the maintenance of the initial progressive motility. B: Incubation period when no motility was observed.

* Untreated secretion.

† Supernatant obtained from a mixture of the fluid from the seminal vesicle with a few drops of secretion of coagulating gland.

\section{TABLE 3}

DURATION OF MOTILITY OF RAT EPIDIDYMAL SPERMATOZOA SUSPENDED IN HANKS' SOLUTION OR IN THE SEMINAL VESICLE SECRETIONS OF THE HAMSTER

\begin{tabular}{c|cc|cr}
\hline & \multicolumn{4}{|c}{ Duration of motility of rat spermatozoa (hr) } \\
\cline { 2 - 5 } $\begin{array}{c}\text { Degree of dilution } \\
\text { (sperm.: solution) }\end{array}$ & \multicolumn{3}{|c|}{ Hanks' solution } & \multicolumn{2}{c}{$\begin{array}{c}\text { Fresh secretion } \\
\text { of seminal vesicle } \\
\end{array}$} & $A$ & $B$ & $A$ & $B$ \\
\hline $1: 1$ & 2 to 4 & 10 to 12 & 4 to 6 & 12 to 24 \\
$1: 3$ & 2 to 4 & 10 to 12 & 6 to 8 & 12 to 24 \\
$1: 5$ & 1 to 2 & 10 to 12 & 8 to 12 & 12 to 24 \\
$1: 8$ & 1 to 2 & 10 to 12 & 8 to 12 & 12 to 24 \\
$1: 10$ & 1 to 2 & 10 to 12 & 6 to 8 & 12 to 24 \\
\hline
\end{tabular}

A: Incubation period for the maintenance of the initial progressive motility. B: Incubation period when no motility was observed.

in the refrigerator at $5^{\circ} \mathrm{C}$ for 1 or 2 days. The factor was also partly inactivated by heating at $56^{\circ} \mathrm{C}$ or $75^{\circ} \mathrm{G}$ for $10 \mathrm{~min}$, and completely inactivated by heating at $90^{\circ} \mathrm{G}$ for $10 \mathrm{~min}$. The beneficial substance could not pass through a collodion 
bag filter (Carl Schleicher \& Schnell Co.), which was estimated to retain proteins of a molecular weight of approximately 70,000 to 100,000 .

TABLE 4

DURATION OF MOTILITY OF RAT EPIDIDYMAL SPERMATOZOA IN THE

SEMINAL VESICULAR SECRETION SUBJECTED TO VARIOUS TREATMENTS

\begin{tabular}{l|cc}
\hline \multicolumn{1}{c|}{ Seminal vesicle secretion } & \multicolumn{2}{|c}{$\begin{array}{c}\text { Duration of motility of } \\
\text { rat spermatozoa (hr) }\end{array}$} \\
& $A$ & $B$ \\
\hline (1) Fresh, untreated & 8 to 12 & 12 to 24 \\
(2) Stored in refrigerator at $5^{\circ} \mathrm{C}$ for 1 or 2 days & 4 to 8 & 10 to 12 \\
(3) Heated at $56^{\circ} \mathrm{C}$ for $10 \mathrm{~min}$ & 6 to 8 & 10 to 12 \\
& $25^{\circ} \mathrm{C}$ for $10 \mathrm{~min}$ & 10 to 12 \\
& $90^{\circ} \mathrm{C}$ for $10 \mathrm{~min}$ & 10 to 12 \\
(4) Non-dialysable through collodion bag & 2 to 12 & 12 to 24 \\
Dialysable through collodion bag & 1 to 4 & 10 to 12 \\
(5) Suspended in Hanks' solution & 10 to 12 \\
\hline
\end{tabular}

A: Incubation period for the maintenance of the initial progressive motility. B: Incubation period when no motility was observed.

\section{TABLE 5}

DURATION OF MOTILITY OF RAT EPIDIDYMAL SPERMATOZOA IN VARIOUS PROTEINS FRACTIONATED FROM RABBIT SERUM

\begin{tabular}{|c|c|c|c|}
\hline \multicolumn{2}{|c|}{ Protein $(0.5 \%)$ or peptide $(0.05 \%)$} & \multirow{2}{*}{\multicolumn{2}{|c|}{$\begin{array}{l}\text { Duration of motility } \\
(\mathrm{hr})\end{array}$}} \\
\hline \multirow[t]{2}{*}{ Fraction } & \multirow{2}{*}{$\begin{array}{c}\text { Electrophoretic } \\
\text { properties }\end{array}$} & & \\
\hline & & $A$ & $B$ \\
\hline $\begin{array}{l}\text { I } \\
\text { II } \\
\text { III } \\
\text { III-0 } \\
\text { IV-1 } \\
\text { IV-4 } \\
\text { V }\end{array}$ & $\begin{array}{l}\text { Fibrinogen } \\
\gamma \text {-Globulin } \\
\beta \text {-Globulins } \\
\beta \text {-Lipoproteins } \\
\alpha \text {-Globulin } \\
\alpha \text {-Globulin } \\
\text { Albumin }\end{array}$ & $\begin{array}{l}0 \text { to } 1 \\
6 \text { to } 8^{*} \\
0 \text { to } 1 \\
0 \text { to } 1 \\
10 \text { to } 12 \\
10 \text { to } 12 \\
10 \text { to } 12\end{array}$ & $\begin{array}{l}10 \text { to } 12 \\
12 \text { to } 24^{*} \\
10 \text { to } 12 \\
10 \text { to } 12 \\
12 \text { to } 24 \\
12 \text { to } 24 \\
12 \text { to } 24\end{array}$ \\
\hline \multicolumn{2}{|c|}{$\begin{array}{l}\text { Glutathione } \\
\text { Cysteine HCl }\end{array}$} & $\begin{array}{l}6 \text { to } 8 \\
4 \text { to } 6\end{array}$ & $\begin{array}{l}12 \text { to } 24 \\
12 \text { to } 24\end{array}$ \\
\hline \multicolumn{2}{|c|}{ Saline diluent (without protein) } & 1 to 2 & 10 to 12 \\
\hline
\end{tabular}

* Agglutination observed.

A: Incubation period for the maintenance of the initial progressive motility. B: Incubation period when no motility was observed.

Electrophoretic pattern of secretions from the seminal vesicle and coagulating gland

Electrophoretic analysis was carried out on the supernatant obtained from hamster seminal vesicular secretion mixed with a few drops of coagulating gland secretion. This was the most effective mixture for the maintenance of the 
motility of rat spermatozoa. Three main fractions were detected in the supernatant and one fraction in the coagulating gland secretion. The mobility of these bands (zones) resembled those of serum $\gamma$ - or $\beta$-globulins.

\section{Ability of purified proteins to maintain motility}

Purified proteins fractionated from rabbit serum by the method of Cohn, Luetscher, Oncley, Armstrong \& Davis (1940) were tested for their ability to maintain rat sperm motility (Table 5). Each fraction was prepared at a concentration of $0.5 \%$ in the diluent. The motility of rat epididymal spermatozoa was maintained for 10 to $12 \mathrm{hr}$ in the diluent containing albumin or $\alpha$-globulins fractionated from rabbit serum. The addition of peptides, such as glutathione or cysteine $(0.05 \%)$ also appeared to assist in maintaining the initial motility of rat spermatozoa (Table 5).

\section{DISCUSSION}

The most striking characteristic of rat epididymal spermatozoa is their high viscosity, which makes it difficult to measure the impedance change frequency (Dott, 1958). Recently, it has been shown that fertilization of rat eggs in vitro is very hard to achieve (Toyoda \& Chang, 1968), and that the metabolic activity of rat spermatozoa is also low (Morita \& Chang, 1971).

In experiments on the storage of rat spermatozoa, Ogawa \& Suzuki (1956) found that motility could be maintained in the supernatant fluids of liver and brain tissue homogenized in either $0.9 \% \mathrm{NaCl}$ solution or $5 \%$ glucose solution. These findings suggest that an organic compound may be necessary for the maintenance of the motility of rat spermatozoa in vitro. In the present studies, the motility of rat spermatozoa was best maintained in the fresh seminal vesicular secretions of the hamster and in the supernatant fluid of the seminal vesicular secretions mixed with a few drops of rat coagulating gland.

Secretion from the seminal vesicles contributes a substantial portion of the whole ejaculate in the rat (Mann, 1964). Schoysman (1958) studied the morphology of the seminal vesicles of the rat and found that after ejaculation, the contents of seminal vesicles were reduced by $50 \%$ but that normal weight was regained after $12 \mathrm{hr}$. According to Howard \& De Feo (1959), the rat seminal vesicular secretion contains $25 \%$ total solids, and an appreciable amount of the ejaculate is normally deposited at mating directly into the uterus. Compared with the prostatic fluid, secretion from the seminal vesicles has a higher dry weight and contains proteins (including some proteose) which can largely be precipitated by trichloroacetic acid (Mann, 1964).

It has now been shown that rat epididymal spermatozoa become immotile when they are mixed with balanced salt solutions and this is somewhat similar to that of the dilution effect, which was demonstrated by Ghang (1946). The studies of mammalian spermatozoa by Emmens \& Swyer (1948), Blackshaw (1953a) and White (1953) indicate that some essential substance is lost during dilution. Such loss can be partly counteracted by the addition of $\mathrm{K}^{+}$to the diluent (Blackshaw, 1953b; White, 1953) or of seminal plasma, or certain large molecular compounds (Ghang, 1959). Wales \& White (1963) also found that the 
viability of diluted dog spermatozoa depends on the presence of proteins (bovine globulin, casein, egg albumin) and alanine, and that in the presence of these substances, which prevent the harmful dilution effect, the motility is as good as in concentrated suspensions. Since some unrelated high molecular weight substances appear to protect the sperm cells from the harmful effects of dilution, Wales \& White (1963) concluded that this effect was due to dilution of the seminal plasma as well as to loss of substances from the cells, suggesting a physical rather than a chemical protective action. The rôles played by the loss of certain substances from the cells, the protective effect of the colloidal substances, and the intracellular changes involved in the dilution effect are still obscure, although Nelson (1967) has suggested that the high molecular weight substances may prevent inactivation of enzymes by dilution.

\section{AGKNOWLEDGMENT}

This work was supported by grants (GM 14370 and K6 HD 18,334) from the U.S. Public Health Service.

\section{REFERENCES}

Blackshaw, A. W. (1953a) The motility of ram and bull spermatozoa in dilute suspension. $\mathcal{F}$. gen. Physiol. 36, 449.

BlaGKshaw, A. W. (1953b) The effects of potassium and calcium salts on the motility of ram, rabbit and bull spermatozoa. F. Physiol., Lond. 120, 465.

Blandau, R. J. \& MONEY, W. L. (1944) Observations on the rate of transport of spermatozoa in the female genital tract of the rat. Anat. Rec. 90, 255.

Blandau, R. J. \& Rumery, R. E. (1961) Fertilizing capacity of rat spermatozoa recovered from various segments of the epididymis. Anat. Rec. 139, 202.

Blandau, R. J. \& RUMERY, R. E. (1964) The relationship of swimming movement of epididymal spermatozoa to their fertilizing capacity. Fert. Steril. 15, 571.

Chang, M. G. (1946) Effect of dilution on fertilizing capacity of rabbit spermatozoa. Science, N.Y. 104,361 .

Chang, M. C. (1959) Fertilizing capacity of spermatozoa. In: Recent Progress in the Endocrinology of Reproduction, pp. 131-163. Ed. C. Lloyd. Academic Press, New York.

Cohn, E. J., Luetscher, J. A., Jr, Oncley, J. L., Armstrong, S. H., Jr \& Davis, B. D. (1940) Preparation and properties of serum and plasma proteins. III. Size and charge of proteins separating upon equilibration across membranes with ethanol-water mixtures of controlled $\mathrm{pH}$, ionic strength and temperature. F. Am. chem. Soc. 62, 3396.

Dotт, H. M. (1958) Species differences in the metabolism of epididymal spermatozoa. Stud. Fert. $10,73$.

Emmens, C. W. (1947) The motility and viability of rabbit spermatozoa at different hydrogen ion concentrations. F. Physiol., Lond. 106, 471.

Emmens, G. W. \& Swyer, G. I. (1948) Observations on the motility of rabbit spermatozoa in dilute suspension. F. gen. Physiol. 32, 121.

Howard, E. \& DE FEo, V. J. (1959) Potassium and sodium content of uterine and seminal vesicle secretions. Am. F. Physiol. 196, 65.

Lawson, R. L., Krise, G. M. \& Sorensen, A. M. (1967) Electro-ejaculation and evaluation of semen from the albino rat. 7. appl. Physiol. 22, 174.

Mann, T. (1964) The biochemistry of semen and of the male reproductive tract. Methuen, London.

MoRITA, Z. \& CHANG, M. G. (1971) The motility and metabolism of spermatozoa in laboratory animals with special reference to the effect of cold shock and the importance of calcium for the motility of hamster spermatozoa. Biol. Reprod. (In press).

NeLson, L. (1967) Sperm motility. In: Fertilization, Vol. I. Eds. C. B. Metz and A. Monroy. Academic Press, New York.

Ogawa, S. \& Suzukr, Y. (1955) Studies on artificial insemination in the rat. I. Induction of pseudopregnancy, collection of semen and technique of insemination. Fap. F. Anim. Reprod. 1, 67. 
OGawa, S. \& Suzukı, Y. (1956) Studies on artificial insemination in the rat. II. Storage of semen with organ homogenate diluent. Fap. F. Anim. Reprod. 2, 55.

OKIGAKI, T. (1958) Observations on the activity of rat spermatozoa taken from the testis and epididymis. Zool. Mag., Tokyo, 67, 169.

Schoysman, R. (1958) Morphology of the seminal vesicle of the rat after electro-ejaculation. C.R. Seanc. Soc. Biol. 152, 1028.

Scotr, J. V. \& Dzruk, P. J. (1959) Evaluation of the electro-ejaculation technique and the spermatozoa thus obtained from rats, mice and guinea pigs. Anat. Rec. 133, 655

SLATER, G. S. (1956) Artificial insemination with testicular tissue; experimental study. F. Urol. 73, 993.

Toyoda, Y. \& Chang, M. G. (1968) Sperm penetration of rat eggs in vitro after dissolution of zona pellucida by chymotrypsin. Nature, Lond. 220, 589.

WALEs, R. G. \& WhITE, I. G. (1963) Viability of diluted dog spermatozoa in vitro. F. Reprod. Fert. 5, 67.

Whrre, I. G. (1953) Metabolic studies of washed and diluted ram and bull spermatozoa. Aust. F. biol. Sci. 6, 706. 